\title{
THE FREEDOM OF INFORMATION IN INDONESIA AND AUSTRALIA
}

\author{
Jodie Partridge \\ Law School, University of Wollongong
}

\begin{abstract}
Freedom of Information laws promote access to data held by government authorities in the public sector to mainstream society. Such laws have been enacted on a global scale; however, the obedience they have attracted is not consistent amongst each geographical location. Freedom of Information Laws has been enacted in Indonesia. It was a scheme introduced in 2008 which included many different components that were to improve each individual's right to communicate and obtain information for the purpose of developing themselves and their current political and social environment. The adequacy of the Freedom of Information is a questionable notion in the grand scheme of Indonesia's legal environment as its effectiveness and motives are rather questionable. It has been acknowledged that this initiative is still developing on a national scale, which raises the main question, is 6 years long enough for a scheme to still be dubbed as 'developing'? This paper will analyse the advantageous and pitfalls of the legislative instrument ending with a comparative analysis with the current situation that Australia experiences.
\end{abstract}

Keywords: Freedom of Information, law, Indonesia, Australia

\section{Introduction}

"Every person has the right to communicate and to obtain information for the purpose of developing themselves and their social environment, and has the right to seek, obtain, possess, store, process and convey information through all available channels" ${ }^{\prime \prime}$. It is founded within this excerpt of Indonesia's Constitution, inserted as a result of the 2000 Bill of Rights that each citizen is inherently deserving of public information. The insertion of this extract stems from the previous legislative landscape that Indonesia fell victim to, commonly referred to as the 'New Order'2. Within this period Indonesia was under the rule of Suharto, who constructed the

\footnotetext{
${ }^{1}$ Undang-Undang Dasar Republik Indonesia 1945, UUD '45 (Indonesian Constitution).

${ }^{2}$ Daniel S. Lev, 'Judicial Authority and the Struggle for an Indonesian Rechsstaat" (1978) 13Law \& Soc'y Rev. 37; Hans Thoolen, Indonesia and the Rule of Law: Twenty Years of "New Order" Government: A Study (London: F. Pinter, 1987).
}

Volume 2(S) No. 1 (2015) 
government to resemble a highly centralised group within a small political elite ${ }^{3}$, a highly corrupt group who did not perceive the 'rule of law' to be a notion of any importance. Whilst it appears that the FOI $\mathrm{Act}^{4}$ is a remedy to the reformation of the corruption that existed, was this the most effective mechanism the government could enact? Did the implementation of this instrument efficiently alter the clouded boundary that existed when citizens requested information regarding Indonesia's public bodies?

Within this article I will critically assess the implementation of the Freedom of Information Act ("FOI") in Indonesia as well as comparatively analysing the rights afforded to those residing in Australia to determine the effectiveness of the government's response to the 'New Era'. I will argue about the whole that whilst the reforms to date are perceived to be somewhat successful, there is a considerable, gaping hole in the legislative landscape that results in the denial of basic rights.

\section{LEGAL MATERIALS AND METHOD}

\section{Research Method}

This paper applies document of legal instruments relating to freedom of information both in Indonesia and the rights afforded to those residing in Australia to determine the effectiveness of the government's response to the 'New Era'. In particular, Indonesian Act Number 14 Year 2008 on Freedom of Information (2008 Freedom of Information Act) will be analyzed. It will use juridical normative method and comparative study. This paper will analyze the implementation of 2008 Freedom of Information Act. Certain articles in mass media, as well as academic papers articles are also extensively used.

\footnotetext{
${ }^{3}$ Ross McLeod, “Soeharto's Indonesia: A Better Class of Corruption” (2000) 7(2) Agenda 99.

${ }^{4}$ Freedom of Information Act 2008 (Undang Undang No. 14 Tahun2008 tentang Keterbukaan Informasi Publik)

${ }^{5}$ Freedom of Information Act 2008 (Undang Undang No. 14 Tahun 2008tentang Keterbukaan Informasi Publik)
}

Volume 2(S) No. 1 (2015) 


\section{Legal Materials}

Legal materials applied in this paper include primary sources and secondary sources as well as tertiary sources, as follows: Primary sources include Indonesian Act number 14 Year 2008 on Freedom of Information Act, United Nation Declaration of Human Rights as well as Indonesian Constitution and relevant Australian legal material, Freedom of Information Act (No.3) 1982 (Cth). Whereas secondary sources to support primary sources analyzes include explanatory section of Indonesian Act Number 14 Year 2008 on Freedom of Information, explanatory section of Indonesian Constitution as well as experts' opinion on relevant matters, relevant academic written paper and Annual Report gained from Central Information Commission of Republic of Indonesia.

\section{III.RESULT AND DISCUSSION}

\section{Explanation of the Act}

As noted above, the driving force behind the FOI $\mathrm{Act}^{6}$ is founded within the reign of Suharto under which corruption flourished, accountability and transparency were not present, and the rule of law was nothing but a myth. The successor to Suharto put in motion reforms that would shape Indonesia's trajectory towards anti-corruption, such as, constitutional reforms, institutional independence of the judiciary from the government, commitments to anti-corruption court, and the most important being the enactment of the FOI $\mathrm{Act}^{7}$ in 2008. The blanket aim of the FOI law is founded within the notion of 'national cohesion'. It declares that by providing heightened access to information the following goals will be achieved; "the increase of the quality of community involvement in decision making, expedite the creation of an open

\footnotetext{
${ }^{6}$ Freedom of Information Act 2008 (UU No. 14 Tahun 2008 tentang Keterbukaan Informasi Publik)

${ }^{7}$ Freedom of Information Act 2008 (UU No. 14 Tahun 2008 tentang Keterbukaan Informasi Publik)
} 
government and encourage public bodies to be" ${ }^{\prime 8}$. To understand the motive of this legislative instrument, the following Articles must be noted:

Article 1(1) 'information is broadly recognised as any information, statement, idea or sign that has value, meaning or a message that can be seen, heard or read'.

Article 1(2) 'public information means information produced, stored, managed or received by a public body which concerns the public interest and either relates to the administration of the state or of another public body ${ }^{10}$.

Article 2(1) 'all public information is to be open and accessible to users of public information which includes Indonesian citizens and legal entities, all citizens and entities possess the right to request, view, understand and obtain a copy of and distribute public information $^{, 11}$

To achieve the desired result as prescribed within the legislation, significant obligations are imposed upon all public bodies in order to encourage their compliance. Such obligations include; the development of information and documentation systems to efficiently manage public information $^{12}$, the creation of request processing systems and to employ staff to respond to requests ${ }^{13}$, and the publishing of six-monthly reports on activities, performance, financial data and any other information that could threaten the necessities of life of the people and public $\operatorname{order}^{14}$. The five central pillars are as follows:

a. Central Information Commission - as a means to ensure compliance with this law the Central Information Commission, an independent commission which operates

\footnotetext{
${ }^{8}$ Daniel S. Lev, above n2.

${ }^{9}$ Freedom of Information Act 2008 (UU No. 14 Tahun 2008 tentang Keterbukaan Informasi Publik) 1(1)

${ }^{10}$ Freedom of Information Act 2008 (UU No. 14 Tahun 2008 tentang Keterbukaan Informasi Publik) 1(2)

${ }^{11}$ Freedom of Information Act 2008 (UU No. 14 Tahun 2008 tentang Keterbukaan Informasi Publik) 2(1)

${ }^{12}$ Simon Butt, Freedom of Information Law and its Application in Indonesia: A Preliminary Assessment,

${ }^{13}$ Ibid.

${ }^{14}$ Ibid.
} (2014) ASJCL p 113-154. 
conjunctively with provincial bodies, was created and attains the primary responsibilities of providing dispute resolution procedures.

b. Dispute Resolution - The FOI Act ${ }^{15}$ puts into place mechanisms for which the public can utilise if they fall victim to a denied request. The process allows for a variety of avenues to be utilised including written reviews, voluntary mediation, public hearing by judicial bodies, and access to the general courts. ${ }^{16}$

c. Exemptions - In accordance with Article $2(2)^{17}$, this legislative instrument does seek to limit the types of information that public bodies can keep secret. The extent to which disclosure takes precedence over transparency relates to the way in which public bodies interpret the content of the law.

d. Harm Consequences Test - Article 2(4) of the FOI Law ${ }^{18}$ establishes what has been labelled as the 'Harm Test :Confidential by reason of statute, appropriateness and the public interest, based on an assessment of the consequences that will arise if the information is disclosed to the community and after considering whether denying access to that information could protect a greater interest than the interest in open access, or vice versa" ${ }^{, 19}$

e. Penalties - It is prescribed within this law that many criminal penalties are attached to offences such as, rejecting a legitimate request for information, falsifying or destroying public information and failure to provide required information as required within the sixmonthly report. Such penalties are attributable to individual culprits or companies, a questionable deterrent to be explored.

\footnotetext{
${ }^{15}$ Freedom of Information Act 2008 (UU No. 14 Tahun 2008 tentang Keterbukaan Informasi Publik)

${ }^{16}$ Simon, Butt, above n12.

${ }^{17}$ Freedom of Information Act 2008 (UU No. 14 Tahun 2008 tentang Keterbukaan Informasi Publik) 2(2)

${ }^{18}$ Freedom of Information Act 2008 (UU No. 14 Tahun 2008 tentang Keterbukaan Informasi Publik) 2(8)

${ }^{19}$ Ibid.
} 
Based upon the explanation provided of the legislative instrument, it is now time to analyse the Act and its implementation. Did it fulfil the expectations of the government and adhere to maintaining the trajectory towards national cohesion?

\section{Effectiveness of the Act}

In order to achieve efficiency, the measurement of this instruments effectiveness will take place with the analysis of certain criteria such as, time and cost effectiveness, precedents set by the Information Commission and an in-depth investigation of the components of the legislation. While many of the criticisms hold considerable merit in the argument they put forth, do they in turn fail to recognise, on a larger scale, the overall evolution of Indonesia?

\section{$\underline{\text { Time and Cost Effectiveness }}$}

The implementation of this law occurred in 2008, its operation occurred fairly sporadically as it did not reach the stage of 'functional' until 2011. In accordance with Article $58^{20}$ and Article $59^{21}$ the Information Commission was to be established within one year of the laws implementation, which did not occur until 2010 and regional provincial commissions were to be established within two years. However, to date only 20 out of 34 provinces currently attain this requirement ${ }^{22}$. According to data obtained from the Central Information Commission, Information Officers were only appointed in the following industries, a condition prescribed by Article $13^{23}$ :

a. 25 of the 35 Ministries (74\%)

b. 29 of 129 State Institutions (22\%)

c. 14 of 33 provincial governments $(42 \%)$

d. 53 of 399 county governments $(13 \%)$

\footnotetext{
${ }^{20}$ Freedom of Information Act 2008 (UU No. 14 Tahun 2008 tentang Keterbukaan Informasi Publik) 58

${ }^{21}$ Freedom of Information Act 2008 (UU No. 14 Tahun 2008 tentang Keterbukaan Informasi Publik) 59

${ }^{22}$ Annual Report 2010, Central Information Commission of Republic of Indonesia, available at www.komisiinformasi.go.id> (last accessed 19 May 2014).

${ }^{23}$ Annual Report 2012, Central Information Commission of Republic of Indonesia, available at <www.komisiinformasi.go.id> (last accessed 19 May 2014).
} 
e. 17 of 98 city governments $(17 \%)^{24}$

The conclusion to be drawn from such statistics provides that slow compliance is currently an issue that is interfering with the success of the legislation, but who is at fault for this? When assessing article $13(\mathrm{~b})^{25}$ it notes that all public bodies were to train and hire employees in order to handle requests for information, however how can such goals be achieved if no government funding, training or procedural guidelines have been developed? It is through such negligence of government activity that an attitude of 'non-compliance' has spread throughout the Indonesian community.

Precedents established by the Information Commission

The performance of the Information Commission in establishing a precedent, and the degree of enforcement in which they are going to adopt has been a fairly developing aspect. According to the Jakarta Post between 2010 and 2011 the Information Commission received 227 requests for information, however only 7 were attended to in a judicial manner and of those 7, only 2 losing parties have been required to comply with the Commission's ruling ${ }^{26}$. A gradual trend of compliance has been identified as, in accordance with the Commission's 2012 annual report, an approximate two thirds of the total 818 requests for information have been resolved ${ }^{27}$. However, whilst a positive trend is depicted, does the way in which they approach them effectively embody the principles of the FOI $\mathrm{Act}^{28}$ ? Two fundamental elements of case law lay the foundation as to the general ability of the Information Commission, which are described as follows:

\footnotetext{
${ }^{24}$ UU Keterbukaan Informasi Diabaikan”, Hukumonline (26 May 2012), online: <www.hukumonline.com> (last accessed 30 October 2013).

${ }^{25}$ Freedom of Information Act 2008 (UU No. 14 Tahun 2008 tentang Keterbukaan Informasi Publik) 13(b) April 2011).

${ }^{26}$ Warief Djajanto Basorie, “Indonesia's Freedom of Information Laws, One Year On”, TheJakarta Post (28

${ }^{27}$ Annual Report 2012, above n23.

${ }^{28}$ Freedom of Information Act 2008 (UU No. 14 Tahun 2008 tentang Keterbukaan Informasi Publik)
} 
1. 'An appeal against West Java Information Commission ordering the Mayor to provide three types of financial documents which due to the following reasons should not have been disclosed:

a. Comprehensive Report Documents are excluded information under the law and should not have been originally disclosed,

b. The report could not be released before obtaining permission,

c. The third report should not have been requested from the Mayor, nor any information to be extracted from his office as it was not his responsibility to produce, store or manage such records, 29 .

2. 'This was an appeal against the central Information Commission decision in the Medan Flood Control Case - The applicant has requested copies of contracts for goods and services. The Ministry challenged the Commission's findings on the basis that the contract has a confidentiality clause and the other party to the contract refused permission for the document to be released. The three grounds in which the Information Commission was incorrect on are:

a. The Ministry had an obligation to fulfil the contract as this contract had a confidentiality clause, they had an obligation to maintain it,

b. The court found that the commercial information contained in the contract was subject to copyright and therefore should not have been subject to disclosure,

c. The Court relied on Article 11(1)(e) of the FOI law ${ }^{30}$ which states that public bodies must provide information about contracts with third parties, however in

\footnotetext{
${ }^{29}$ Bogor Mayor v. Hidayat (Bandung Administrative Court Decision 34/G/TUN/2012 PTUN-BDG); Bogor Mayor v. Hidayat (Bandung Administrative Court Decision 64/G/TUN/2012 PTUN-BDG).

${ }^{30}$ Freedom of Information Act 2008 (UU No. 14 Tahun 2008 tentang Keterbukaan Informasi Publik) 11(1)(e)
}

Volume 2(S) No. 1 (2015) 
this instance no third part was present and disclosure was therefore not required, $^{31}$.

Whilst it is perceived that increased compliance with the act is a positive aspect which has been slowly generating since its inception, the manner in which it is correctly interpreted and enforced is highly questionable. The apparent need for the Administrative Appeals Court to overturn the commission's original decisions allows for a degree of doubt as to what rights are actually being afforded to Indonesian citizens?

\section{Analysis of the Acts Components}

The imperative component to this text analysis is determining whether the components of the act effectively provide an avenue to the 'Freedom of Information' or if this is merely an instrument to evade further global scrutiny.

In accordance with the Association of the Rule of Law, 'The scope of Indonesia's Law on Public Information Transparency was a compromise between the government and civil society. The government did not want to bring State Owned Enterprises within the scope of the law however, civil society organisations demanded it. The result was a compromise where such enterprises were required to disclose limited classes of information, ${ }^{32}$. Although it appears that a compromise was an effective response, critics argue that an abundance of information is left undisclosed, for example 'it does not require disclosure of information related to the contract actually awarded nor is there any disclosure of information that would allow the public to evaluate its performance, such as statistics concerning output ${ }^{33}$.

A vital component of the FOI Law ${ }^{34}$ is the 'harm test' which provides public bodies with the authority to deny information on a variety of bases. The legal foundation for such power is

\footnotetext{
${ }^{31}$ Public Works Ministry v. Antoni Fernando (Jakarta Administrative Court Decision 102/G/2012/PTUNJKT).

${ }^{32}$ Angela Migally, Freedom of Information: A Cornerstone of Democratic Transition (2013) p20 - 21.

${ }^{33}$ Ibid.

${ }^{34}$ Freedom of Information Act 2008 (UU No. 14 Tahun 2008 tentang Keterbukaan Informasi Publik)
} 
founded within Article $6^{35}$ as it is declared that 'public bodies have the right to refuse to provide information that is 'excluded by' or 'does not accord' with 'written laws', which are any form of government law, from statutes through to regulations, presidential instructions, ministerial decrees and circulars and local parliament by-laws ${ }^{36}$. To follow on from this avenue of exemption, Article $2(4)^{37}$ establishes a proportionality test, where the public-interest in disclosure is balanced against the impending harm that disclosure might bring from a plain reading of the legislature. It appears that if the information officer believes the admission of particular information will be more detrimental to the public interest than advantageous, then disclosure can be repudiated ${ }^{38}$. It is viewed that Article $2(4)^{39}$ has the potential to expand 'excluded information' beyond the categories already specified within Articles $17^{40}$ and $6(3)^{41}$. Through this possibility it is therefore inherently possible that any information could be subjectively categorised as more harmful if released or against the public interest. The pitfall of this provides public bodies with the ability to individually decipher whether the avoidance of disclosure is a more appropriate response, meaning a debate between their motives and the public's rights has the potential to never result in the latter.

Another component targeted by critics is the legislature's inability to provide a definition of a 'public body'. According to a professor of Gadjah Mada University, the characterisation afforded to a 'public body' is too broad and causes obscurity when classifying between public and private entities ${ }^{42}$. This acts as a fundamental weakness as many entities have the ability to evade their obligations by claiming they do not possess the characteristics of a public body and

\footnotetext{
${ }^{35}$ Freedom of Information Act 2008 (UU No. 14 Tahun 2008 tentang Keterbukaan Informasi Publik) 6

${ }^{36}$ Ibid.

${ }^{37}$ Freedom of Information Act 2008 (UU No. 14 Tahun 2008 tentang Keterbukaan Informasi Publik) 2(4)

${ }^{38}$ Ibid.

${ }^{39}$ Freedom of Information Act 2008 (UU No. 14 Tahun 2008 tentang Keterbukaan Informasi Publik) 2(4)

${ }^{40}$ Freedom of Information Act 2008 (UU No. 14 Tahun 2008 tentang Keterbukaan Informasi Publik) 17

${ }^{41}$ Freedom of Information Act 2008 (UU No. 14 Tahun 2008 tentang Keterbukaan Informasi Publik) 6(3)

${ }^{42}$ Adistra Kusuma Waligalit, Legal Proposition on the Public Freedom of Information in Indonesia (2013) Faculty of Law of Gadjah Mada University p $1-7$.
}

Volume 2(S) No. 1 (2015) 
no obligation to respond to information requests. An example of this is founded within the report of the Association of the Rule of Law which notes that the lack of transparency within private entities is a contributory factor to many human rights breaches, resulting in the recommendation for the release of all legal, financial and auditing reports for companies, cooperatives and military based entities ${ }^{43}$.

Further aspects of the legislature that have fallen under scrutiny although are not as vital as the abovementioned components are:

1. The inability of wholly deterrent penalties to be prescribed within Article 52 and 53 of the FOI Act ${ }^{44}$. The most effective element of the penalties under this instrument are its ability to target individuals who intentionally evade their obligations, however such a positive element is overshadowed by the inability of the Information Commission to issue penalties, and the minimal financial burden it can place on public bodies; and

2. There have been many instances in which the Information Commission has not responded to an individual's appeal within the specified timeframe and therefore do not afford elements of procedural fairness to all parties ${ }^{45}$.

It is through such elements of analysis that I will now be in a position to provide an overall evaluation of this instrument.

\section{Evaluation of the Act}

As noted by the multiple critics, the evolution towards 'freedom of information' in Indonesia has been a slow and moderate journey. Whilst advances are evidenced in terms of providing a trajectory towards the rule of law and the recognition of fundamental human rights, the elements of accountability and transparency are yet to be achieved. After an assessment of the components of the act and the precedents that have failed to be followed by the Information

\footnotetext{
${ }^{43}$ Angela Migally, above $\mathrm{n} 32$.

${ }^{44}$ Freedom of Information Act 2008 (UU No. 14 Tahun 2008 tentang Keterbukaan Informasi Publik) 52, 53

${ }^{45}$ No 144/KMA/SK VIII/2007 on Disclosure of Information in Court.
} 
Commission, Indonesia is yet to reach the pinnacle of providing an effective response to the demand for Information. To strengthen the inadequacies of Indonesia's response to this issue, I will now undertake a brief comparative analysis between the rights afforded to Australian citizens as opposed to those of Indonesia.

\section{Comparative Analysis between the rights afforded to Australian and Indonesian citizens}

According to the United Nations Educational, Scientific and Cultural Organisation, as a response to global demands Australia developed and enforced their national FOI Law ${ }^{46}$ as early as $1982^{47}$. The Australian Government enacted this legislation with the motive of providing citizens with an insight as to policy making, administrative decision making, government service delivery and the ability to search and modify all records that attain personal information ${ }^{48}$. The most notable differences, bar the initial motives and time of implementation of the legislature, between the Australian and Indonesian landscapes are, the Australian Government seeks to actively and regularly promote awareness of FOI opportunities, they regularly audit on an internal and external basis their ability to fulfil their obligations as per their legislative requirements, both public and private entities are susceptible to the FOI Law ${ }^{49}$ and the Australian government maintains a heightened level of compliance to the legislative instrument by frequently providing information and procedural guidelines to both public and private entities. An example of the level of adherence and importance the Australian government provides to the freedom of information is founded within their yearly audit submitted to Parliament titled 'Review of Freedom of Information Legislation' ${ }^{, 50}$ which includes statistics, data and ideas of reform in order to provide each citizen with the level of rights they are entitled to.

\footnotetext{
${ }^{46}$ Freedom of Information Act (No. 3) 1982 (Cth)

${ }^{47}$ Freedom of Information in Asia Pacific (2013) United Nations Educational, Scientific and Cultural Organisation: Communication and Information

${ }^{48}$ Ibid.

${ }^{49}$ Freedom of Information Act (No. 3) 1982 (Cth)

${ }^{50}$ John McMillan and James Popple, Review of Freedom of Information Legislation (2012) Office of the Australian Information Commissioner p 47.
} 
It is through this comparative analysis that the words 'transparency' 'accountability' and 'national cohesion' cannot straightforwardly be applied to the Indonesian Government and the manner in which they address the 'freedom of information'.

\section{CONCLUSION}

The beginning of this text included a quote founded within the Indonesian Constitution that acknowledged the basic right that each citizen is deserving of, but when taking into account the evidence provided and the above analysis, the question of whether the Constitution is being wholly fulfilled arises. On a general note it is indisputable that the legal landscape of Indonesia has improved significantly since the inception of the FOI Act in $2008^{51}$. To an extent it has established a degree of press freedom and has acted as a component to remedy the damage caused by the 'New Order'. However, its effectiveness is significantly queried. In my opinion and based upon the above opinions of various criticisms, the notion of 'freedom of information' in Indonesia is yet to be achieved on a scale that embodies principles of accountability and transparency. Summarily the implementation of this instrument did not efficiently alter the clouded boundary that exists when citizens attempt to obtain information regarding Indonesia's government, public bodies or personal items.

\section{REFERENCES}

\section{Articles/Books/Journals}

Basorie, Warief Djajanto "Indonesia's Freedom of Information Laws, One Year On”, The Jakarta Post (28 April 2011)

Butt. Simon, Freedom of Information Law and its Application in Indonesia: A Preliminary Assessment, (2014) ASJCL p 113-154

\footnotetext{
${ }^{51}$ Freedom of Information Act 2008 (UU No. 14 Tahun 2008 tentang Keterbukaan Informasi Publik)
} 
Lev, Daniel "Judicial Authority and the Struggle for an Indonesian Rechsstaat" (1978) 13

Law \& Soc'y Rev. 37; Hans Thoolen, Indonesia and the Rule of Law: Twenty Years of "New Order"

Government: A Study (London: F. Pinter, 1987)

McLeod, Ross “Soeharto’s Indonesia: A Better Class of Corruption” (2000) 7(2) Agenda 99

McMillan, John and Popple, James, Review of Freedom of Information Legislation (2012) Office of the Australian Information Commissioner $\mathrm{p} 47$

Migally, Angela. Freedom of Information: A Cornerstone of Democratic Transition (2013) p20 21

UU Keterbukaan Informasi Diabaikan, Hukumonline (26 May 2012), online: www.hukumonline.com (last accessed 30 October 2013)

Waligalit, Adistra Kusuma Legal Proposition on the Public Freedom of Information in Indonesia (2013) Faculty of Law of Gadjah Mada University p 1 - 7

\section{Cases}

Bogor Mayor v. Hidayat (Bandung Administrative Court Decision 34/G/TUN/2012 PTUNBDG); Bogor Mayor v. Hidayat (Bandung Administrative Court Decision 64/G/TUN/2012 PTUN-BDG).

Public Works Ministry v. Antoni Fernando (Jakarta Administrative Court Decision 102/G/2012/PTUN-JKT).

\section{Legislation}

Freedom of Information Act 2008 (UU No. 14 Tahun 2008 tentang Keterbukaan Informasi Publik)

Freedom of Information Act (No. 3) 1982 (Cth)

\section{Other}

Undang-Undang Dasar Republik Indonesia 1945, UUD '45 (Indonesian Constitution)

Annual Report 2012, Central Information Commission of Republic of Indonesia, available at <www.komisiinformasi.go.id> (last accessed 19 May 2014).

Annual Report 2010, Central Information Commission of Republic of Indonesia, available at www.komisiinformasi.go.id> (last accessed 19 May 2014).

No 144/KMA/SK VIII/2007 on Disclosure of Information in Court. 
Freedom of Information in Asia Pacific (2013) United Nations Educational, Scientific and Cultural Organisation: Communication and Information 